\title{
Calling signal pattern vs. genitalia morphology in Planaphrodes Hamilton, 1975 (Homoptera: Auchenorrhyncha: Cicadellidae: Aphrodinae) - which trait evolves faster?
}

\section{Структура призывнбх сигналов и морфология гениталий у Planapbrodes Hamilton, 1975 (Homoptera: Auchenorrhyncha: Cicadellidae: Aphrodinae) - какой признак эволющионирует быстрее?}

\section{D.Yu. Tishechkin \\ A.Ю. Тишечкин}

Department of Entomology, Faculty of Biology, M.V. Lomonosov Moscow State University, Vorobyevy Gory, Moscow 119234, Russia. Email: macropsis@yandex.ru

Кафедра энтомологии Биологического факультета Московского государственного университета имени М.В. Ломоносова, Воробьёвы Горы, Москва 119234, Россия.

KEY WORDS: Homoptera, Auchenorrhyncha, Cicadellidae, Planaphrodes, calling signals, morphology, evolution.

КЛЮЧЕВЫЕ СЛОВА: Homoptera, Auchenorrhyncha, Cicadellidae, Planaphrodes, призывные сигналы, морфология, эволюция.

ABSTRACT. Male calling signals and genitalia of four species of Planaphrodes were investigated. In $P$. laevus and P. elongatus, penis stem is slender with two pairs of processes in the middle part, whereas in $P$. bifasciatus and $P$. monticola it is wide in lateral view with three pairs of processes; the level of interspecific morphological differences within each pair of species is approximately the same. However, in $P$. laevus and $P$. elongatus, signal patterns are distinctly different and share only one similar component, whereas in P. bifasciatus and $P$. monticola signals are almost identical. Convergent origin of such an elaborate signal patterns in last two species is hardly possible. The more probable alternative is a subdivision of the range of the ancestral form in two parts which resulted in morphological divergence, whereas signal patterns in both forms remained unchanged. Thus, in some cases morphological traits can evolve faster than the acoustic signal pattern; examples of signal similarity in other taxa of leafhoppers and grasshoppers confirm this hypothesis.

РЕЗЮМЕ. Исследованы призывные сигналы и гениталии самцов четырёх видов Planaphrodes. У $P$. laevus и $P$. elongatus ствол пениса узкий, с двумя парами отростков в средней части, у P. bifasciatus и P. monticola он дорзовентрально расширен и несёт три пары отростков; в целом, уровень морфологических различий между видами в обеих парах примерно одинаков. Несмотря на это, у P. laevus и $P$. elongatus сигналы существенно различаются и имеют только один сходный компонент, в то время как у P. bifasciatus и P. monticola они почти идентичны. Конвергентное возникновение столь сложных сигналов у двух последних видов маловероятно. По-видимому, разделение ареала предковой формы привело к морфологической дивергенции, в то время как паттерн сигналов у обоих дочерних видов остался неизменным. Таким образом, в некоторых случаях морфологические признаки могут эволюционировать быстрее, чем паттерн акустических сигналов; примеры сходства сигналов в других таксонах цикадовых и саранчовых подтверждают эту гипотезу.

\section{Introduction}

It is generally believed that in insects using acoustic signals for recognition of conspecific mate, signal pattern evolves faster than morphological traits. Different authors offer different explanations for this phenomenon, but everyone confirms that species-level differences in signal pattern fairly often evolve in a relatively short time [Henry, 1985; Tishechkin, Vedenina, 2016]. For this reason acoustic analysis is widely used for discrimination between morphologically similar species. Presently, many articles on taxonomy of Orthoptera and singing cicadas (Homoptera: Auchenorrhyncha: Cicadidae) include signal oscillograms and/or sonograms along with morpho-

How to cite this article: Tishechkin D.Yu. 2019. Calling signal pattern vs. genitalia morphology in Planaphrodes Hamilton, 1975 (Homoptera: Auchenorrhyncha: Cicadellidae: Aphrodinae) — which trait evolves faster? // Russian Entomol. J. Vol.28. No.3. P.227-232. doi: 10.15298/rusentj.28.3.01 
logical descriptions [Ragge, Reynolds, 1998; Sueur, Puissant, 2003, 2007, etc.]. Recording of low-amplitude vibrational signals requires more sophisticated equipment, but in some taxa using vibrational communication e.g., in lacewings (Neuroptera: Chrysopidae) and leafhoppers (Homoptera: Auchenorrhyncha: Cicadellidae) acoustic analysis presently is also successfully used for solving taxonomic problems [Henry et al., 2009; Tishechkin, 2019a, etc.].

However, different biological species producing similar or even identical signals are known in many insect taxa. Such species avoid acoustic interference due to partitioning of a time of singing activity, different ecological preferences, etc. [Henry, Wells, 2010; Tishechkin, 2010; Tishechkin, Bukhvalova, 2010].

In taxa producing signals with simple temporal pattern, the number of possible variables in signal structure is very small. Usually, these are duration of a signal as a whole and of its components and a repetition period of these components. In such a situation, accidental independent emergence of similar signals in unrelated species is possible. For example, in most families of Fulgoroidea (Homoptera: Auchenorrhyncha) signals are rather uniform. Occasionally, signals with almost identical patterns can be found even in species from different families, e.g. in Cixius nervosus (Linnaeus, 1758) (Cixiidae) and $\mathrm{Al}$ loscelis vittifrons (Ivanov, 1885) (Issidae) [Tishechkin, 2008]. Among Homoptera, examples of this kind are also known in plant lice (Psyllinea) [Tishechkin, 2006] and in a leafhopper tribe Paralimnini (Auchenorrhyncha: Cicadellidae: Deltocephalinae) [Tishechkin, 2007, 2010].

Sometimes, within the subfamily or the tribe several main types of signal pattern can be distinguished. Signals of congeneric species can belong to different types, whereas signals of species from different genera can belong to the same type. This situation is observed in gomphocerine grasshoppers (Orthoptera: Acrididae: Gomphocerinae) [Tishechkin, Bukhvalova, 2010] and in Delphacinae (Homoptera: Auchenorrhyncha: Delphacidae) [Tishechkin, 2008]. This phenomenon can be explained by retaining of the same motor program of neurons that drive muscles of sound apparatus, in different phylogenetic lineages.

Finally, similar signals sometimes exist in closely related allopatric species. For example, in two sisterspecies, Macropsis flavida Vilbaste, 1980 from the mainland part of the Eastern Palaearctic and M. remota Tishetshkin, 1998 from Sakhalin (Homoptera: Auchenorrhyncha: Cicadellidae: Macropsinae) calling signal patterns are identical in spite of the fact that these forms have distinct although small morphological differences and apparently, already reached the rank of good species [Tishechkin, 2019b].

In the present paper we provide an example of similarity of calling signal patterns in a leafhopper genus Planaphrodes Hamilton, 1975 (Homoptera: Auchenorrhyncha: Cicadellidae: Aphrodinae). This case is interesting because, first, the signals have very elaborate patterns and their independent emergence in different species is highly unlikely and, second, species producing similar signals differ distinctly in genitalia shape.

\section{Material and methods}

Male vibrational calling signals were recorded by means of portable recording equipment consisting of a piezocrystal gramophone cartridge GZP-311 connected to the microphone input of a cassette recorder Elektronika-302-1 (before 2005), minidisk recorder Sony Walkman MZ-NH900 (2005-2016), or Roland R-05 wave/ mp3 recorder (from 2017) via a custom-made matching amplifier. For recording, a twig of the host plant about $10-15 \mathrm{~cm}$ in length was attached to the cartridge by a rubber ring so that the cartridge needle touched the stem slightly. Then a nylon cage containing a male leafhopper was put on the twig. After a time, the male usually sat on the twig and started singing. Signal analysis was performed with Cool Edit Pro 2.1 software.

For elements of signal temporal pattern the following terms are used. Pulse is a brief elementary fragment of signal (or succession of sine waves) with rapid increase and subsequent decrease of amplitude, i.e. separated from similar fragments by amplitude minimums. Short fragments with constant temporal pattern usually repeated with regular intervals and consisting of uniform or different pulses are referred to as syllables. Any more or less prolonged signal with complex pattern (e.g. succession of similar or different syllables) is referred to as a phrase.

All males whose signals were investigated were dissected. The drawings of penis were made from specimens whose signals were recorded, by tracing the outlines of digital photographs on a glass table lighted from underneath. All materials studied are deposited in the collection of the Zoological Museum of M.V. Lomonosov Moscow State University.

\section{Results}

All species of the genus Planaphrodes are mediumsized (ca. 4-6 mm) stout leafhoppers. Males have a very distinctive dark brown coloration with three wide white transverse stripes; in some species forewing tips are also white. Despite the similarity in coloration, all known species are well distinguished by the penis shape [Hamilton, 1975]. Planaphrodes usually dwell on the soil surface or in the upper layer of the litter among plant remnants.

Descriptions of male calling signal pattern and penis shape in four species studied are given below.

\section{Planaphrodes laevus (Rey, 1891)} Figs 1-7.

MATERIAL. 1. Russia, Moscow Oblast, Voskresensk District, dry meadow with xerophyte vegetation on the Western edge of Beloozerskiy Town, from Artemisia campestris L., 1.VII.2018, signals of five males recorded at $27{ }^{\circ} \mathrm{C}$ (Figs 2, 4-6).

2. Russia, Northern Caucasus, Northern Ossetia, the Ardon River Basin, env. Zintsar Village, xerophyte vegetation on stony slopes, 4.VIII.1990, signals of two males recorded at $21^{\circ} \mathrm{C}$.

3. Russia, Altai Mountains, Southern end of the Teletskoe Lake, slope with steppe vegetation, 18.VII.1999, signals of two males recorded at $24-25{ }^{\circ} \mathrm{C}$ (Figs $1,3,7$ ).

SIGNALS. Calling signal is a phrase lasting for ca. 10-20 s. It begins with a sequence of similar pulses following each other with a repetition period of 50-100 ms. The main part of 
1

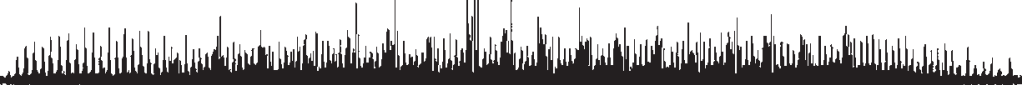

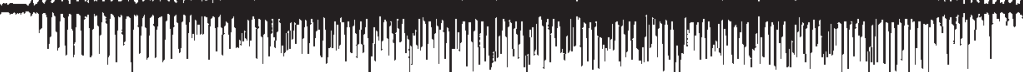

\section{3}

$2 s$

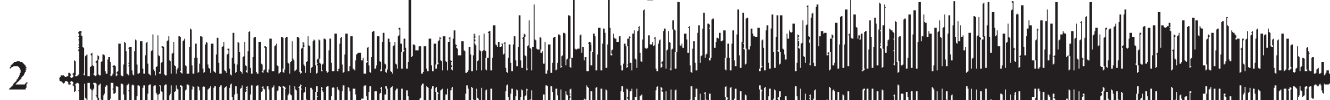

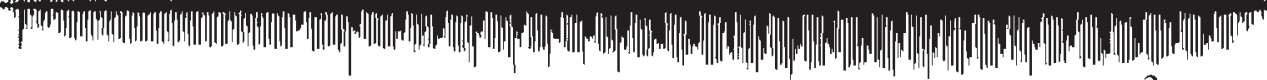

3

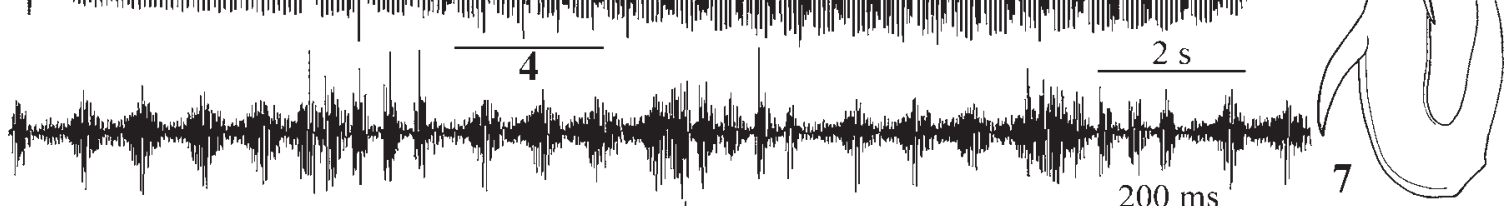

4

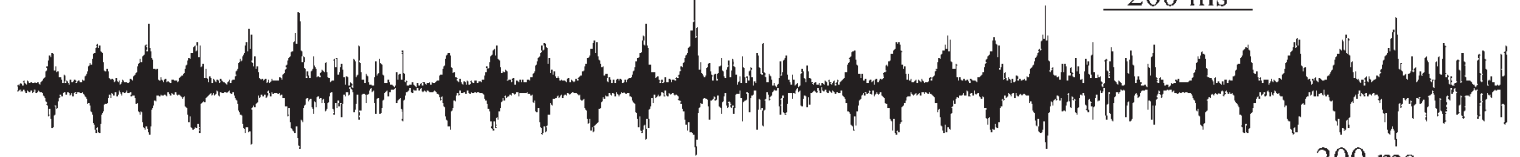

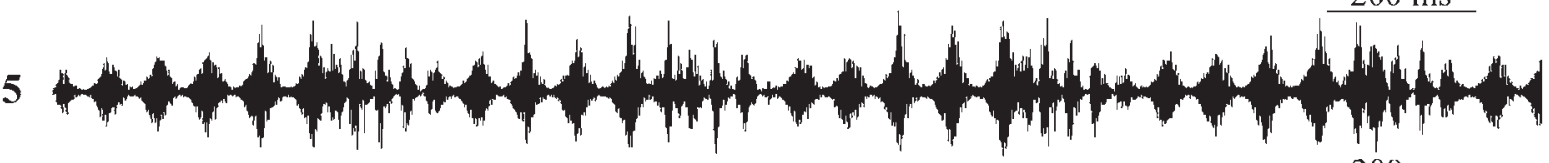

6

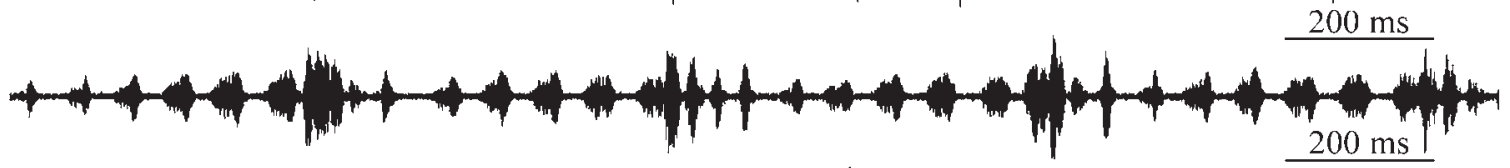

8

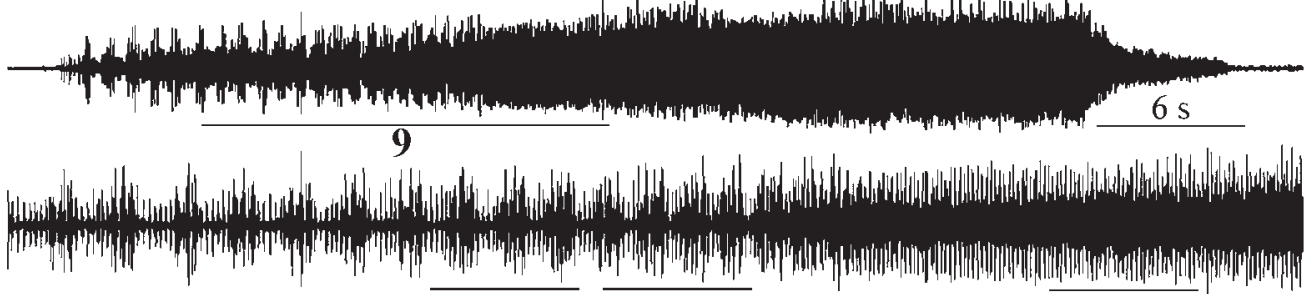

9

10

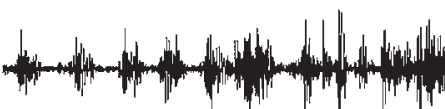

$$
10 \quad 11
$$

13

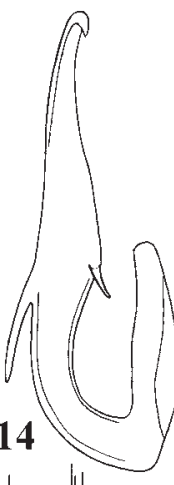

11

(n)

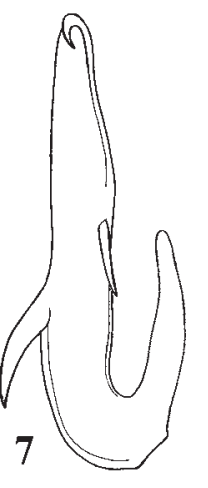

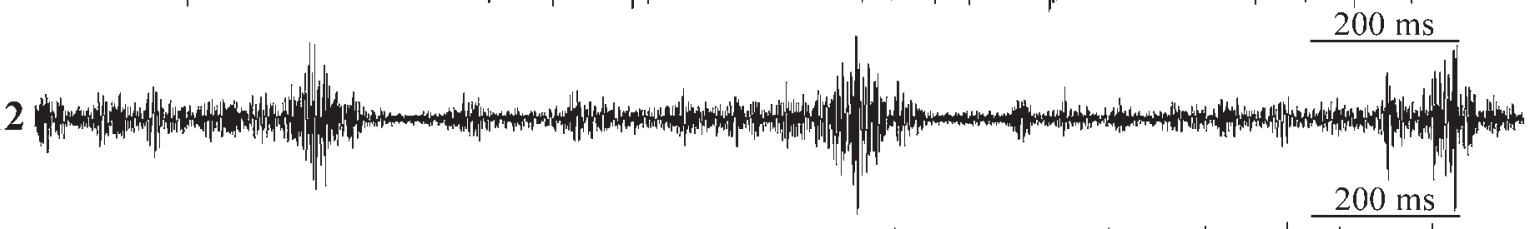

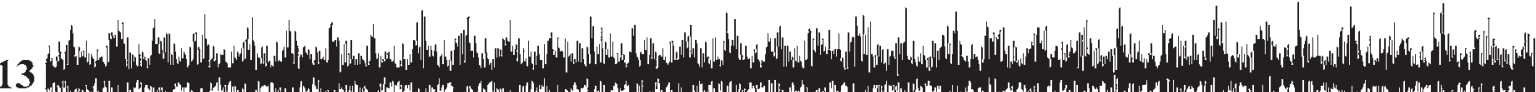

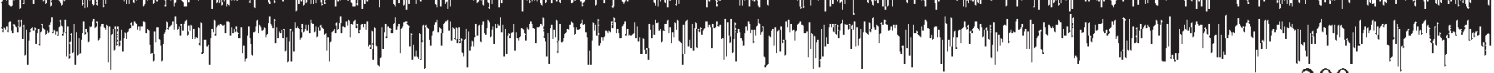
Oblast; 12 and 14 - male from Astrakhan Oblast. Faster oscillograms of the parts of signals indicated as "3-4", "9-11", and "13" are given under the same numbers.

Рис. 1-14. Planaphrodes spp.: 1-7 - P. laevus; 8-14-P. elongatus; 1-6, 8-13- осциллограммы призывных сигналов самца; 7, 14 - пенис сбоку; 1, 3, 7 - самец с Алтая; 2, 4-6 - самцы из Московской обл.; 8-11, 13 - самец из Саратовской обл.; 12, 14 - самец из Астраханской обл. Фрагменты сигналов, обозначенные цифрами “3-4”, “9-11” " “13”, представлены на осциллограммах под такими же номерами. 
$15-1$ -

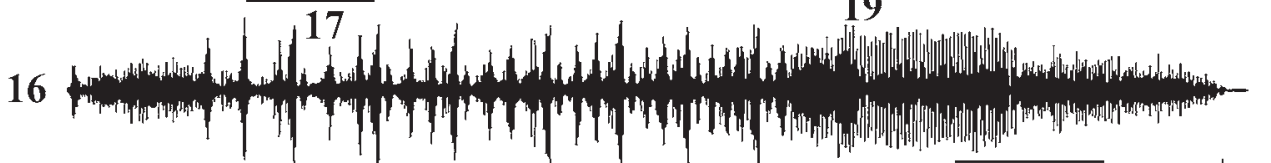
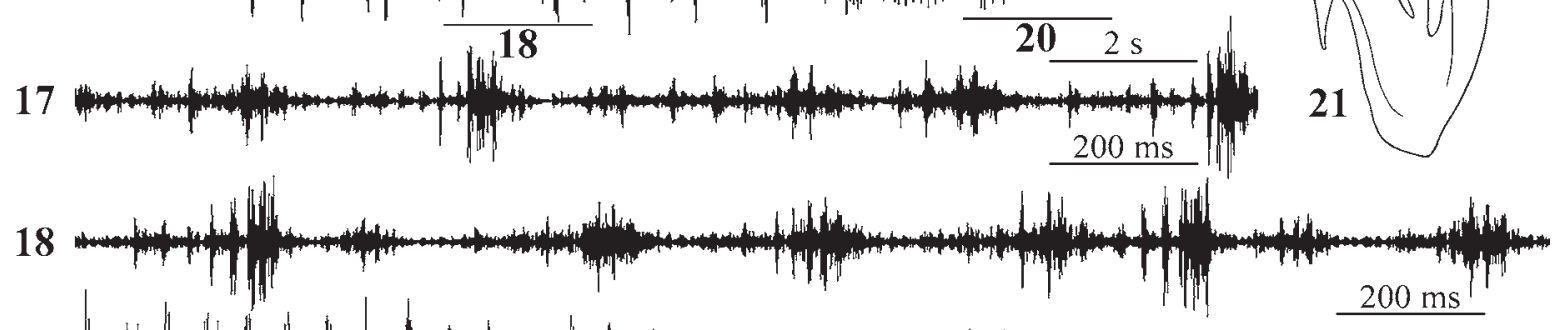

19

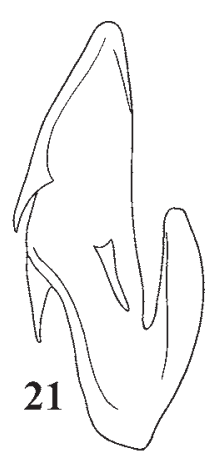

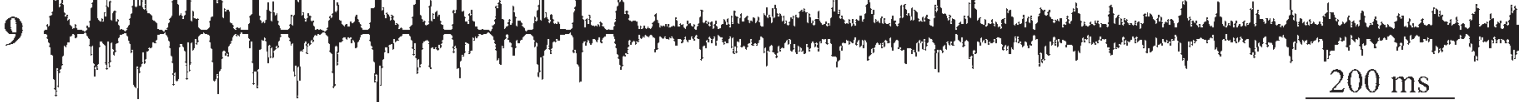

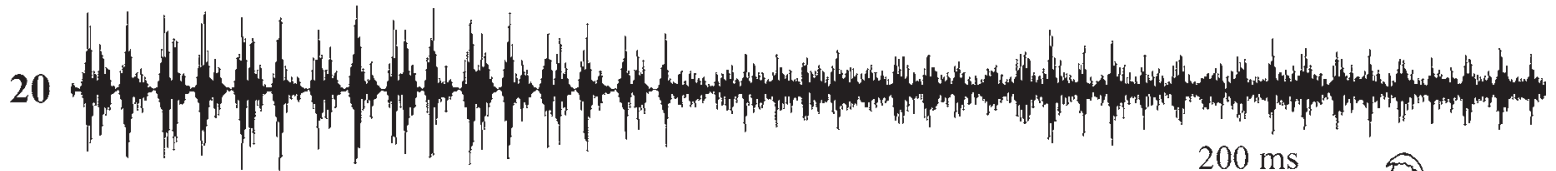

22

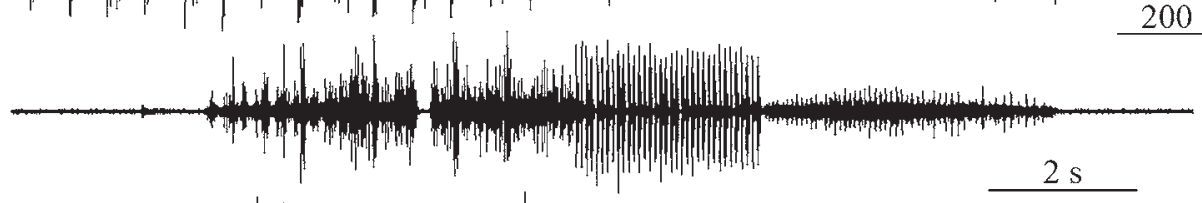

23

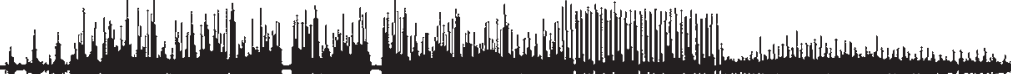
Thy

$$
\frac{1}{25} \frac{2 s}{27}-\frac{2 s}{2}
$$

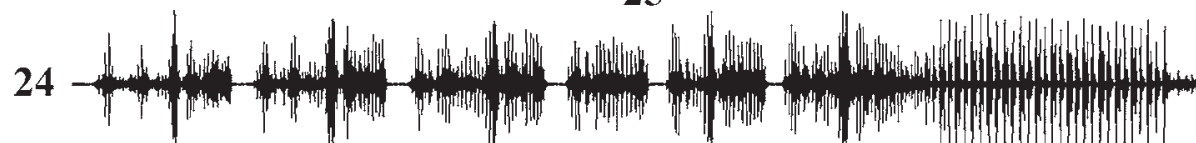

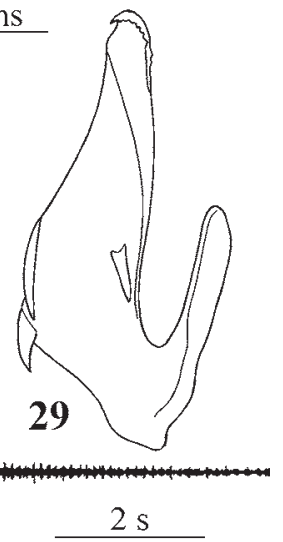
W. W.

25

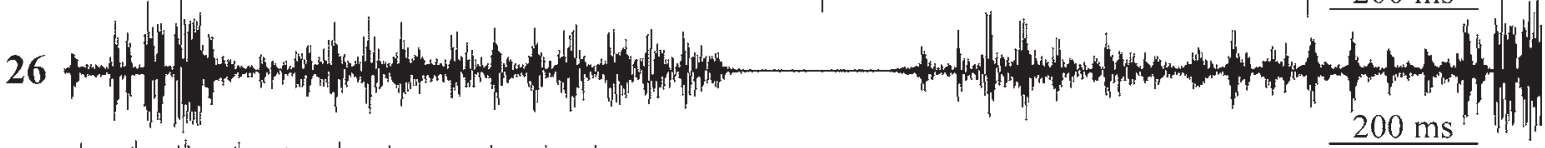

27 f f

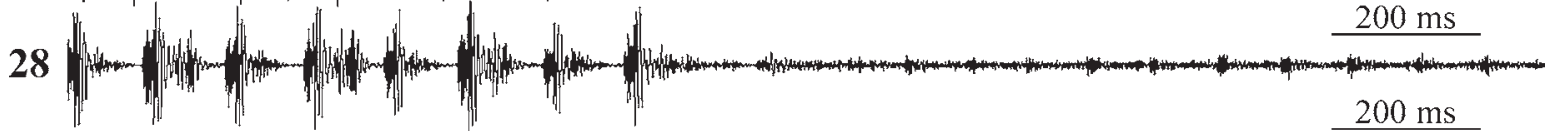

Figs 15-29. Planaphrodes spp.: 15-21 - P. bifasciatus; 22-29-P. monticola; 15-20 and 22-28 - oscillograms of male calling signals; 21 and 29 - penis, side view; 15, 17, and 19 - male from Mytishchi District; 16, 18, and 20-21 — male from Serpukhov District (both in Moscow Oblast); 22-23, 25, 27, and 29 - male from Western Tien-Shan Mts.; 24, 26, and 28 - male from Central Tien-Shan Mts. Faster oscillograms of the parts of signals indicated as "17-20" and " $25-28$ " are given under the same numbers.

Рис. 15-29. Planaphrodes spp.: 15-21 - P. bifasciatus; 22-29 - P. monticola; 15-20, 22-28 - осциллограммы призывных сигналов самца; 21, 29 - пенис сбоку; 15, 17, 19 - самец из Мытищинского р-на; 16, 18, 20-21 — самец из Серпуховского р-на (оба Московская обл.); 22-23, 25, 27, 29 - самец с Западного Тянь-Шаня; 24, 26, 28 - самец с Центрального Тянь-Шаня. Фрагменты сигналов, обозначенные цифрами “17-20” и “25-28”, представлены на осциллограммах под такими же номерами. 
a phrase consists of syllables repeating with a period of ca. 400-550 ms. Each syllable includes 4-6 pulses of the same shape as at the beginning of a phrase, and a complex variable component consisting of several shorter pulses partially merged with each other. Amplitude relation of two parts of a syllable can differ in different signals (Figs 3-6). The phrase ends with the same succession of pulses as in the beginning.

PENIS SHAPE. Penis in side view slender, with a pair of large ventral processes, a pair of shorter dorsal processes, and small apical ones (Fig. 7).

\section{Planaphrodes elongatus (Lethierry, 1876)} Figs 8-14.

MATERIAL. 1. Russia, extreme Southeast of Saratov Oblast, 2-3 km East of Ozinki Town, in the steppe near the pool, 5.VII.2004, signals of one male recorded at $26-27{ }^{\circ} \mathrm{C}$ (Figs 8-11, 13).

2. Russia, Astrakhan Oblast, Western Shore of the Baskunchak Lake, near Bol'shoy Bogdo Mtn., 4.VII.2005, signals of two males recorded at $29-30{ }^{\circ} \mathrm{C}$ (Figs 12,14 ).

SIGNALS. Calling signal is a very long phrase lasting from $40-50 \mathrm{~s}$ up to 3-4 min and consisting of two different parts. The first part consists of syllables repeating with a period of about 400-800 ms; syllable pattern is somewhat similar to this in the signal of $P$. laevus (cf. Fig. 9, the $1^{\text {st }}$ half of the oscillogram and Figs 1-2), but on high-speed oscillograms distinct interspecific differences are visible (Figs 1012 and 3-6). Similarly to $P$. laevus, amplitude relation of two parts of a syllable can differ in different signals (Figs 10-11 and 12). The second part of a phrase consists of partially merged short syllables with indistinct temporal pattern and repeating with a period of 40-70 $\mathrm{ms}$.

PENIS SHAPE. The length ratio of the penis processes and their position are the same as in P. laevus, but the shape of penis stem is different (Fig. 14).

\section{Planaphrodes bifasciatus (Linnaeus, 1758)} Figs 15-21.

MATERIAL. 1. Russia, Moscow Oblast, Mytishchi District, env. Pirogovo Town, dry meadow, from Trifolium repens L., 2.VII.1988, signals of one male recorded at $27^{\circ} \mathrm{C}$ (Figs 15, 17, 19).

2. Russia, Moscow Oblast, Serpukhov District, env. Luzhki Village, dry meadow near the Oka River, from Medicago falcata L., 30.VI.1988, signals of two males recorded at $27^{\circ} \mathrm{C}$ (Figs 16, 18, 20-21).

SIGNALS. Calling signal is a phrase lasting for about 10 $20 \mathrm{~s}$ and consisting of three different parts. The first part consists of rather variable syllables repeating with a period of ca. $0.8-1.1 \mathrm{~s}$. The second part consists of high-amplitude syllables including two pulses each or, more rarely, of single pulses; in our recordings, syllable repetition period in this part averages 50-60 ms. The third part has considerably lower amplitude compared to the second one and is similar to the $2^{\text {nd }}$ part of a phrase of $P$. elongatus (cf. Figs 13 and 19-20, the $2^{\text {nd }}$ halves of oscillograms); syllable repetition period in this part averages 40-50 ms. Male can produce single phrases with irregular intervals (Fig. 15) or sing almost continuously for several minutes (Fig. 16). In the latter case phrases can follow each other without gaps (the end of the previous phrase presents in the beginning of the oscillogram on Fig. 16).

PENIS SHAPE. Penis broad in lateral view, with two pairs of processes in the middle of a ventral part and a pair of processes on the sides closer to the dorsal edge; apical part simple, rounded (Fig. 21).

Planaphrodes monticola (Logvinenko, 1965) Figs 22-29.

MATERIAL. 1. Kyrgyzstan, Western Tien-Shan Mts., Chatkal'skiy Mtn. Range, Northern shore of the Sary-Chelek
Lake, 26.VII.2008, signals of one male recorded at $27-28^{\circ} \mathrm{C}$ (Figs 22-23, 25, 27, 29).

2. Kyrgyzstan, Central Tien Shan Mts., the Kekemeren River Basin, the Western Karakol River ca. $10 \mathrm{~km}$ from the mouth (10 km East-North-East from Suusamyr Village), mountain steppes on the right bank, 6.VII.2016. Signals of one male recorded at $21{ }^{\circ} \mathrm{C}$ (Figs 24, 26, 28).

SIGNALS. Calling signal is similar to the signal of $P$. bifasciatus, but differ from it by the presence of gaps in the first part, by somewhat different temporal pattern of syllables in it, and by lower amplitude of the third part.

PENIS SHAPE. Similar to $P$. bifasciatus by wide penis stem and the position of processes in its middle part, but differs from it by the shape of a stem and the presence of small serrated apical processes (Fig. 29).

\section{Discussion}

By the penis shape the four species studied can be classified in two pairs. Within each pair the general shape of penis and the number and position of processes in the main part of its stem are similar. In P. laevus and $P$. elongatus, penis stem is slender with two pairs of processes in the middle part, whereas in P. bifasciatus and $P$. monticola it is wide in lateral view with three pairs of processes. In both cases two species differ from each other by the outlines of penis stem in lateral view and by the shape of its apical part. Thus, it can be assumed that the level of morphological divergence between $P$. laevus and P. elongatus is approximately the same as between P. bifasciatus and P. monticola.

Signal temporal pattern remains constant within each species and is almost identical even in males from different geographical points; the only signal parameter that demonstrates significant variability is a phrase duration.

In $P$. laevus and $P$. elongatus, signal patterns are distinctly different and share only one somewhat similar component, a succession of syllables. In P. laevus this succession forms the main part of a phrase, whereas in $P$. elongatus it forms the first part of a phrase; on oscillograms at low speed these components are similar (cf. Figs $1-2$ and $9,1^{\text {st }}$ half of the oscillogram), but at high speed clear differences are visible (cf. Figs 3-6 and 10-12).

Signals of $P$. elongatus on one hand, and of $P$. bifasciatus and P. monticola on another, also share one similar component, the final succession on partially merged syllables. Signals of $P$. laevus are completely different from signals of P. bifasciatus and P. monticola.

On the contrary, in P. bifasciatus and P. monticola signals are almost identical. Convergent origin of such an elaborate signal pattern in these two species is hardly possible. The more probable alternative is a subdivision of the range of the ancestral form in two parts which resulted in morphological divergence and subsequent speciation, whereas signal patterns remained unchanged in both species newly emerged.

Thus, in some cases morphological traits can evolve faster than the acoustic signal pattern. Meanwhile, the ratio of the rates of changes in morphology and signals can differ even within the genus. In four species studied, in spite of approximately the same degree of morphological difference between P. laevus and P. elongatus and 
between $P$. bifasciatus and $P$. monticola, in the first pair of species signals share only one similar component, whereas in the second pair they are almost identical.

$P$. bifasciatus and $P$. monticola have overlapping ranges. For example, both species were recorded from Arslanbob, Ferghana Mtn. Range, Kyrgyzstan by Dubovskiy [1966; P. monticola is listed as Aphrodes tricinctus (Curtis, 1836)]. We always collected Planaphrodes species on meadows or in steppes among mixed herbaceous vegetation; neither of the species studied demonstrated strong host specialization. Moreover, insect vibrational signals can spread from plant to plant through contiguous stems and even roots. For this reason, in sympatric species of grass-dwelling Auchenorrhyncha even differences in host specialization by no means always provide segregation of vibratory communication channels [Tishechkin, 2011]. Thus, $P$. bifasciatus and $P$. monticola, being formally sympatric, apparently, inhabit different plant communities to avoid overlapping of acoustic niches. Indeed, we have never found more than one species of Planaphrodes in the same biotope.

Examples of signal pattern similarity in sympatric species are also known in some other taxa of Auchenorrhyncha. Two Central Asian cixiid species, Reptalus narynensis Emeljanov et Tishetshkin, 2012 and $R$. nigrovenosus (Kusnezov, 1937) (Homoptera: Auchenorrhyncha: Cixiidae) produce similar signals, have overlapping ranges and similar ecological preferences, but were never found in the same biotope [Emelyanov, Tishechkin, 2012]. Similar signals were also recorded in some sympatric species of Limotettix (Scleroracus) Van Duzee, 1894 (Homoptera: Auchenorrhyncha: Cicadellidae: Deltocephalinae); as in the previous case, in spite of similar ecological preferences they were never collected in the same biotope [Tishechkin, 2019a]. As in Planaphrodes, in both cases cited above, species studied differ from each other in the shape of male genitalia and/or in coloration; consequently, morphological divergence was faster than the divergence in acoustic traits. However, in Reptalus and in Limotettix (Scleroracus) calling signals have much simpler pattern and are similar in most species within each of these genera.

The same situation is also known in other insect taxa. For example, two species of gomphocerine grasshoppers, Chorthippus macrocerus (Fischer-Waldheim, 1846) and Ch. vagans (Eversmann, 1848) (Orthoptera: Acrididae: Gomphocerinae) are sympatric and produce similar signals. However, in Rostov Oblast where our investigations were conducted, these two species were never found together, but replaced each other in different habitats [Tishechkin, Bukhvalova, 2010].

Thus, small, sometimes almost elusive, and not always clear for to the researcher differences in biotope preferences can contribute to the communication channel segregation in insect species producing signals with similar pattern. In such cases detailed studies of biotope preferences is necessary to reveal factors responsible for ecological niche partitioning.

Acknowledgements. The study was carried out in the framework of the Russian State program No. AAAA-A16-
116021660095-7 with the support of Russian Foundation for Basic Research, grant No. 19-04-00073.

\section{References}

Dubovskiy G.K. 1966. [Cicadinea (Auchenorrhyncha) of Ferghana Valley]. Tashkent: Fan Publ. 256 pp. [in Russian].

Emelyanov A.F., Tishechkin D.Y. 2012. Contributions to the study of the genus Reptalus Emeljanov, 1971 (Homoptera: Auchenorrhyncha: Cixiidae) of Western Tien Shan Mountains // Russian Entomological Journal. Vol.21. No.3. P.309-314.

Hamilton K.G.A. 1975. A review of the Northern Hemisphere Aphrodina (Rhynchota: Homoptera: Cicadellidae) with special reference to Nearctic fauna // Canadian Entomologist. Vol.107. No.10. P.1009-1027.

Henry C.S. 1985. Sibling species, call differences, and speciation in green lacewings (Neuroptera: Chrysopidae: Chrysoperla) // Evolution. Vol.39. No.5. P.965-984.

Henry C.S., Mochizuki A., Nakahira K., Haruyama N., Nomura M. 2009. Courtship songs of Chrysoperla nipponensis (Neuroptera: Chrysopidae) delineate two distinct biological species in eastern Asia // Annals Entomol. Soc. Amer. Vol.102. P.747-758.

Henry C.S., Wells M.M. 2010. Acoustic niche partitioning in two cryptic sibling species of Chrysoperla green lacewings that must duet before mating // Animal Behaviour. Vol.80. P.991-1003. doi:10.1016/j.anbehav.2010.08.021

Ragge D.R., Reynolds W.J. 1998. The songs of the grasshoppers and crickets of Western Europe. Harley Books, England (in association with The Natural History Museum, London). 591 pp.

Sueur J., Puissant S. 2003. Analysis of sound behaviour leads to new synonymy in Mediterranean cicadas (Hemiptera: Cicadidae: Tibicina) // Deutsche Entomologische Zeitschrift. Bd.50. No.1. S.121-127.

Sueur J., Puissant S. 2007. Similar look but different song: a new Cicadetta species in the montana complex (Insecta: Hemiptera: Cicadidae) // Zootaxa. Vol.1442. No.1. P.55-68.

Tishechkin D.Yu. 2006. Vibrational communication in Psylloidea (Homoptera) // S. Drosopoulos, M.F. Claridge (eds.). Insect Sounds and Communication. Physiology, Behaviour, Ecology and Evolution. Boca Raton, London, New York: CRC Press, Taylor and Francis Group. P.357-363.

Tishechkin D.Yu. 2007. Similar calling signals in different species of leafhoppers (Homoptera: Cicadellidae): an example of Paralimnini // Russian Entomol. Journal. Vol.16. No.2. P.265-272.

Tishechkin D.Yu. 2008. On the similarity of temporal pattern of vibrational calling signals in different species of Fulgoroidea (Homoptera: Auchenorrhyncha) // Russian Entomological Journal. Vol.17. No.4. P.343-351.

Tishechkin D.Yu. 2010. Vibrational signals in sympatric species of leafhoppers: Paralimnini (Homoptera: Cicadellidae: Deltocephalinae) in the valley of Irkut River, Eastern Siberia a case study // Russian Entomol. Journal. Vol.18 (for 2009). No.4. P.265-272.

Tishechkin D.Yu. 2011. Do different species of grass-dwelling small Auchenorrhyncha (Homoptera) have private vibrational communication channels? // Russian Entomological Journal. Vol.20. No.2. P.135-139.

Tishechkin D.Yu. 2019a. Review of species of Limotettix (Scleroracus) Van Duzee, 1894 (Homoptera: Auchenorrhyncha: Cicadellidae: Deltocephalinae) of the fauna of Russia with description of a new cryptic species from Sakhalin // Zootaxa. Vol.4544. No.2. P.214-234.

Tishechkin D.Yu. 2019b. Leafhoppers of the genus Macropsis Lewis, 1836 (Homoptera: Auchenorrhyncha: Cicadellidae: Macropsinae) on Sakhalin - different evolutionary trends in different species // Russian Entomological Journal. Vol.28. No.2. P.107-119.

Tishechkin D.Yu., Bukhvalova M.A. 2010. Acoustic communication in grasshopper communities (Orthoptera: Acrididae: Gomphocerinae): segregation of acoustic niches // Russian Entomol. J. Vol.18 (for 2009). No.3. P.165-188.

Tishechkin D.Yu., Vedenina V.Yu. 2016. [Acoustic signals in insects: a reproductive barrier and a taxonomic character] // Zoologichesky Zhurnal. Vol.95. No.11. P.1240-1276 [in Russian, with English summary]. English translation: Entomological Review. 2016. Vol.96. No.9. P.1127-1164. 